„Bohemistyka” 2020, nr 1, ISSN 1642-9893

\title{
Iluzivní postupy ve vzpomínkových textech Ignáta Herrmanna ${ }^{1}$
}

Keywords: memory, Ignát Herrmann, fiction, non-fiction, narrative ways Klíčová slova: paměti, Ignát Herrmann, fikce, non-fikce, narativní způsoby

\section{Abstract}

The paper is focused on the memory books by czech writer Ignát Herrmann, especially on the problem of border between nonfiction and fictional narrative. Herrmann drawn up his memory books as factual narrative, however but in some parts of his texts we can observe interesting narrative techniques, which shifts the narration towards fictionality. Our goal in this study is detected this parts and analysis them on the background not only the others parts, which are represented factual narration, but in compare with fictional narration by Jan Neruda.

Studie je zaměřena na vzpomínkové knihy Ignáta Herrmanna, zejména na problematiku hranice mezi non-fikčním a fikčním vyprávěním. Herrmann svoje knihy vzpomínek koncipoval jako faktuální vyprávění, nicméně v některých jeho částech vzpomínek koncipoval jako faktuální vyprávění, nicméně v některých jeho částech tyto části detekovat a analyzovat na pozadí nejen ostatního Herrmannova faktuálního vyprávění, ale také ve srovnání s fikčním u Jana Nerudy.

1.

Vztahy mezi uměleckou fikcí a non-fikcí, at' již nonfikcí myslíme diskurzivní reprezentace aktuálního světa nebo jeho možných neaktualizovaných verzí, tvoří jedno z hlavních témat teoretického uvažová-

${ }^{1}$ Studie vznikla v rámci grantu GA ČR 18-04420S, Proměny narativních způsobů $v$ české próze I. Za cenné připomínky a návrhy děkuji doc. PhDr. Alici Jedličkové, CSc. 
ní o problematice fikčních světů, které se zdaleka netýká jen vlastní literární teorie, ale významně ovlivňuje i další disciplíny, především lingvistiku, logiku a filozofii. Tuto situaci reprezentují také dva do češtiny přeložené sborníky příspěvků $\mathrm{k}$ teorii fikce, ve kterých jsou kromě literárněteoretických studií zastoupeny i studie $\mathrm{z}$ jiných vědních oborů, mimo jiné i z oblasti teoretické fyziky. ${ }^{2}$ Ačkoli je na problematiku fikčních světů nahlíženo z hlediska odlišných disciplín, společné je jim konstatování o komplikovaném poměru fikčních světů - at' jsou tyto nahlíženy z hlediska filozofie jako tzv. sekundární ontologie nebo fenomény (viz Oullet 2017), logiky jako projevy a manifestace parakonzistentních systémů (viz Woods 2017), z hlediska jazyka jako projevu předstíraných řečových aktů atd. - ke světům nonfikčním. To platí nejen v případě oborově specifického přístupu, ale rovněž z hlediska epistemologie, kdy lze rozlišit mezi přístupem tzv. segregacionistickým a integracionistickým. ${ }^{3}$ Problematika poměru mezi fikcí a nonfikcí není izolována od řady jiných otázek, respektive od dalších kategorií, jak to vyjádřil Thomas Pavel:

Je třeba rozlišovat mezi metafyzickými otázkami fikčních entit a pravdy; demarkačními otázkami vztahujícími se k možnosti stanovit jasné hranice mezi fikcí a nonfikcí jak v teorii, tak v praktické kritice; a institucionálními otázkami vztahujícími se k místu a významu fikční literatury coby kulturní instituce (Pavel 2012, s. 31).

Samozřejmě bychom tuto triádu mohli rozšiŕĭit mimo jiné o neméně podstatnou dimenzi komunikační, jejíž proměňující se povaha s ohledem na status textu coby fikčního nebo nonfikčního komunikátu determinuje a problematizuje kategorie autora a čtenáře.

\footnotetext{
${ }^{2}$ Jedná se o publikace Možné světy $v$ humanitnich vědách, $v$ uměni a v při rodnich vědách (2012) a O fikci nově (2017).

${ }^{3}$ Srov.: ,,[S]egregeacionisté mezi fikci a nefikci vkládají kategorickou dělící čáru a povahu fikce vysvětlují jako odchylku od aktuálního stavu věccí, od standardn logiky a od normálních sémantických pravidel. [...] Integracionisté potlačují ontologické rozlišení mezi světy a vyhlašují bezproblémovou př́stupnost ze systému jednoho světa do druhého" (Ronenová 2006, s. 19, 20).
}

V této studii bychom se rádi soustředili na konkrétní př́klad realizace vztahu a poměru mezi modem směřujícím $\mathrm{k}$ fikci a non-fikcí, a to na vybraných vzpomínkových textech Ignáta Herrmanna. Jak známo, Herrmann kromě své beletrie publikoval řadu drobnějších textů dokumentární povahy mapujících postupně zanikající svět staré Prahy a jejích obyvatel. Tyto mnohdy literárně stylizované memoáry staropražského prostředí Herrmann publikoval zčásti časopisecky od druhé poloviny 80 . let 19 . století do poloviny 20 . let 20 . století dvacátého, souborně potom vyšly v knihách Bodři Pražané (1. vyd. 1893), Před padesáti lety (3 svazky, 1924, 1925, 1926), ${ }^{4}$ O živých, o mrtvých (3 svazky, 1915, 1928, 1940). Ačkoli jsou tyto texty samotným autorem zamýšleny jako vzpomínkový dokument, lze v nich objevit zajímavé př́iklady prostupování dokumentární faktičnosti s literární fikcionalizací. ${ }^{5}$ To samo o sobě nemusí být nějakým překvapivým zjištěním, uvážíme-li, že tyto svého druhu paměti píše literát, navíc s jednoznačným úmyslem evokovat zašlou atmosféru zanikající staré Prahy. Naším úkolem tedy nebude dohledávat jednotlivé doklady, které by dokumentovaly tuto dvojakost a podporovaly právě uvedené tvrzení, ale spíše se pokusíme zaměřit na způsoby, jakým dochází $\mathrm{k}$ překračování této velmi jemné a neostré hranice mezi fakticitou a fikcí, řečeno jinak, našim cílem bude sledovat, jak faktické a fikční koexistují takříkajíc na společném prostoru, a to v konfronatci s texty primárně zamýšlenými jako literární, fikční.

\section{2.}

Tř́isvazkový soubor vzpomínek Před padesáti lety byl publikován v polovině 20. let dvacátého století. Herrmann se v nich vrací do Prahy

\footnotetext{
${ }^{4}$ Výbor z uvedných knih vyšel pod názvem O Praze a Pražanech (1959).

${ }^{5}$ Záměrně používáme tento pojem, abychom jím vymezili tendenci $\mathrm{k}$ fikčnosti a současně tento proces odlišili od fikce jakožto komplexního status quo. Fikcionalizaci chápeme jako tendenci k fikčnosti, tj. k strukturně-sémantické a posléze i ontologické autonomizaci. Na místě je rovněž termín iluzivnost (popřípadě literárnost), který jsme použili i v názvu studie.
} 
70. a 80. let 19. století, ve které si všímá všech jejích atributů, které v moderní době, zejména pak po asanaci na přelomu 19. a 20. století nenávratně vymizely. Ke zvláště oblíbeným náleží kupříkladu pražské kašny a s nimi spojený život staropražských služek, kterým autor věnuje dvě kapitoly a upozorn̆uje, že by toto téma ve skutečnosti vyžadovalo samostatné a mnohem rozsáhlejší pojednání, ${ }^{6}$ ke kterému ovšem nemá prostor, nebot' do své knihy potřebuje vměstnat vzpomínky na další kuriozity staropražského života. Vyjdeme tedy z těchto textů, abychom si na nich zprvu demonstrovali znaky a celkovou povahu Herrmannových vzpomínek a jejich dokumentárnost.

$\mathrm{V}$ prvé řadě tuto žánrovou povahu textů jmenovaných souborů předznamenává již jeho název, respektive podnázev Drobné vzpomínky z minulosti. Samozřejmě se nelze při žánrovém určení spoléhat pouze na vlastní název, ale je nezbytné reflektovat i paratexty, strukturně-sémantickou povahu textu nebo zohlednit pragmaticko-recepční kritéria. Je totiž možné, aby text nebo jeho části, jež náleží k žánru memoáru nebo dokumentu, při relativně nezměněné povaze velmi dobře fungovaly jako součást literárního díla, a tedy se funkčně podílely na generování komplexní fikční dimenze jakožto sekundární ontologie. Toto pravidlo však může platit i opačně, jak ukazuje i nedávno publikovaná studie Zuzany Foniokové o problematice autofikce (viz Fonioková 2018).

Pokusme se za účelem nalezení distinktivních rysů signalizujících fikční a non-fikční diskurz (narativ) porovnat následující čtyři ukázky, z nichž první dvě jsou z Nerudových Povídek malostranských, zbývající dvě pak z Herrmannových vzpomínek. Na tomto místě je nezbytné upozornit, že ono hledání kritérií fikcionality a non-fikcionality nemá univerzální platnost, ale výhradně se vztahuje ke zde pojednávaným textům.

${ }^{6}$ „Bývalé pražské kašny vyžadovaly by vlastně pro svůj nějkdejší význam zvláśtního pojednání historického', ač nebylo-li něco podobného někdy již napsáno, o čemž arci nevím" (Herrmann 1959, s. 81).
Bylo by směšné, kdybych pochyboval, že některý z mých čtenářů nezná malostranský hostinec U Štajnicủ. (A) Přední to tamější restaurace; první dům za Mosteckou věží vlevo, roh ulice Mostecké a Lázeňské, velká okna, skleněné velké dvéře. Jediná restaurace, která se směle postavila do nejveřejnější ulice, otvírajíc se k tomu ještě př́ímo na chodník, - všechny restaurace ostatní jsou bud' ve vedlejších ulicích, nebo se do nich vchází domem, nebo mají alespoň před sebou podloubí, v pravé malostranské skromnosti. (B) Proto také pravý Malostraňák, syn těch tichých, zamlklých ulic, plných poetických zákoutí, k Štajnicům nejde. Chodí tam vyšší úřadníci, profesoři, důstojníci, jež tam na Malou Stranu zavála náhoda a brzy snad zase odtamtud odvěje, s nimi pak jen málo ještě penzistů, několik starých, bohatých domácích pánů, kteř́ živnost svou dávno již odevzdali jiným, a dost. Ráz byrokraticko-aristokratický. Již před lety, když jsem byl ještě drobným gymnazistou, byla společnost u Štajniců podobného výlučného rázu, přec ale v jistém ohledu jiná (Neruda 1966, s. 79).

Chodil vždy s kloboukem v ruce. At' byl sebevětší úpal mrazový nebo sluneční, nanejvýš že držel svůj nízký, ale baňatý cylindr se širokou střechou nad hlavou jako parazol. Šedivé vlasy byly hladce přičísnuty $\mathrm{k}$ lebce a spojovaly se vzadu v cůpek tak pevně stlačený a svázaný, že se ani nekýval, - jeden to z nejposlednějších cůpků v Praze, už tenkráte byly tu jen dva nebo tři. Zelený fráček jeho, se zlatými knoflíky, měl živůtek jen krátký, zato byly ale šosy dlouhé a tloukly hubenou, malou postavičku páně Rybáŕovu do vychrtlých lýtek. Bílá vesta kryla nahnutá prsa, černé spodky šly jen po kolena, kde se svítily dvě stříbrné přazky, pak dál byly sněhobílé punčochy zas až $\mathrm{k}$ jiným dvěma stř́brným přazkám a pod těmi šouraly se velké střevíce. Byly-li ty střevíce někdy obnovovány, nevím, ale vždycky vypadaly tak, jako by se k nim byla brala rozpraskaná kůže ze střechy nejstaršího fiakra.

Suchý, špičatý obličej páně Rybářův byl ozářen věčným úsměvem (s. 120). [3.]

Za našich školáckých let rok co rok jsme se nedočkavě těšivali na „ostatky”. MC Mladší čtenáři myslí si tu: Na jakéžpak ostatky?

${ }^{7}$ OČ $=$ oslovení čtenáře, $\mathbf{L}=$ lokace, $\mathbf{T}=$ čas, $\mathbf{T M}=$ téma 
Arcit', sám jsem toho slůvka již dávno neslyšel a zdá se mi, že snad už nadobro vymizelo z našeho života $\mathrm{v}$ tom smyslu, jaký tehdy mělo. Časem jen je čítáme na oněch smutečních listech s širokým černým rámcem, na nichž bývá zmínka o „tělesných ostatcích", ale v novější době již i tu bývá užíváno jiných obratů slohových. Tehdy však, před padesáti, před šedesáti lety značily nám ,ostatky" něco velmi veselého a zvláště horlivé mládeži školní velmi vítaného. Bylyt’ to „ostatky masopustní”, poslední dva dny v masopustě, pondělí a úterý před Popeleční středou, a my vzorní školáci proto jsme se na ně tolik těšívali, že jsme na ten ostatkový úterek dostávali „fraj”, jak nám pan učitel vždy oznamoval (Herrmann 1926, s. 155-156).

[4.]

Kulatá, veliká hlava, kulatý, veliký, skoro bych řekl rozlehlý obličej; ta veliká hlava sedí na silném, mohutném krku, ale pod tím vším krátké, tlusté tělo na krátkých nohou, cupajících drobnými kroky. Skoro si nelze představiti přívětivější, vlídnější, upřímnější tváře. Leží na ní, vždy pečlivě holené, tolik starosvětské dobroty, kolem úst krouži laskavý, sousedský úsměv, a dvé modrých očí hladí tak bodře, bezstarostně, sdílně do světa a utkvívá na vás tak prátelsky, že byste starochovi s chutí řekli: tatínku! A vypadá jako dobrák venkovský tatík, který nabaživ se starostí a zaopatřiv rodinu, a nemaje oč by dále pečoval, zapadl do Prahy, aby tu strávil zbytek života (Herrmann 1959, s. 121).

Veškeré tyto ukázky jsou iniciálními částmi bud’to konkrétních povídek anebo vzpomínkových textů. Jak si můžeme všimnout, uvedené ukázky je možné porovnat tak, že spojíme první a třetí, druhou a čtvrtou, $\mathrm{k}$ čemuž nás opravňují některé analogické rysy a postupy $\mathrm{v}$ těch to textech. V první a třetí ukázce je realizováno vypovídající já, které je jednou ich-formovým vypravěčem a podruhé autorským subjektem. (K této problematice se ještě podrobněji vrátíme.) V obou př́padech ovšem můžeme pozorovat, že autor nebo vypravěč iniciuje další obsah tím, že jej rámuje místně $(\mathbf{L})$ a časově $(\mathbf{T})$. V prípadě ukázky z Nerudovy povídky Pan Ryšánek a pan Schlegl je následující př́běh lokálně zasazen do malostranského hostince, přičemž vzápětí dochází k bližší specifikaci místa pomocí kratšího popisu a charakteristiky místa, čemuž v ukázce odpovídají části $\mathbf{A}$ (deskriptivně nocionální) a B (deskriptivně charakterizační). Časově je př́iběh odkazován do minulosti (T) vzhledem k času vyprávění. Podobné rysy lze vysledovat také v Herrmannově vzpomínce na staropražské masopustní veselí, která je součástí jmenovaného souboru Před padesáti lety. Jestliže v první ukázce iniciaci dominuje lokální zarámování, v prŕípadě ukázky číslo 3 se jedná o časové. To samozřejmě ještě neznamená, že by zde chyběla lokální určení, kterým je prostě Praha. Iniciační rámování místem nebo časem velmi dobře slouží jako vstupní předpoklady pro rozvíjení událostí či příběhu, které mohou být jednou fikční povahy, jindy povahy non-fikční, de facto dokumentární. V obou př́padech se rovněž setkáváme s vypravěčovým nebo autorovým oslovením čtenáře a opět platí, že jednou je této narativní strategie využito ve prospěch fikce, podruhé non-fikce.

Podívejme se na další dvě ukázky, které jsou pod čísly 2 a 4 . Nejenže jsou obě vyprávěny rétoricky deskribujícím vypravěčem, ale současně je $\mathrm{v}$ obou prípadech zvolena analogická strategie deskripce postavy, která začíná od dílčího popisu (obvykle hlavy a obličejových partií) a směřuje $\mathrm{k}$ celé postavě. Podobně jako $\mathrm{v}$ předchozím př́padě $\mathrm{i}$ $\mathrm{v}$ tomto, pokud bychom předem neznali textové zdroje, mohli bychom se snadno a jistě oprávněně domnívat, že ve všech př́padech jde o začátky různých povídek a že tyto vstupní pasáže textově iniciují fikční světy. Stejně bychom se však mohli domnívat, že se vůbec nejedná o literární fikci, ale o autorovy vzpomínky na doby dávno minulé, totiž na starou Prahu, a tedy v důsledku o texty, které nekonstruují fikci, ale jež se vztahují sice $\mathrm{k}$ zaniklé, přesto však ke skutečnosti. $^{8}$

V těchto př́ipadech jsme tedy odkázáni na paratexty a na kulturně podmíněné znalosti o textech a jejich paradigmatech, které jednou recipujeme jako fikci, jindy jako dokument. $\mathrm{K}$ čemu ovšem dojde, pokud takový jednoznačný paratext nemáme $\mathrm{k}$ dispozici? Bud'to zcela chybí, anebo si nejsme na základě paradigmatických kritérí jisti, kam

${ }^{8}$ Jak upozorňuje Emanuel Frynta v doslovu k výboru O Praze a Pražanech, i když v Herrmannových vzpomínkách ,[i]ntelektuální přehled a historicky obzíravá úvaha chybí”, jsou především poutavým čtením, vzpomínkovu prózou (Frynta 1959, s. 258). 
konkrétní text situovat, zdali primárně do sféry umění anebo dokumentu. Jedním z distinktivních kritérií, jimiž se oba typy textů odlišují, je situace autora a vypravěče. Gérad Genette rozlišuje mezi demiurgem-autorem $\mathrm{v}$ př́padě non-fikčních textů a demiurgem-vypravěčem tam, kde se jedná o literární díla produkující fikční světy. Někdy ovšem ani na takovém analytickém základě provedené rozlišení nemusí fungovat spolehlivě. Genette ostatně sám vyslovil pochybnost o povaze Nervalovy nedokončené prózy Aurelie, kterou se zdráhal beze vší pochybnosti označit za čistou literární fikci; podobně též Bretonovu Nadju (viz Genette 2007, s. 62). V případě romantického spisovatele, a navíc u Gérada de Nerval, jehož tvorba a osobní život byly velmi úzce, až osudově provázány, nemusí být jednoznačně rozlišeno, co je dílem a co kupř́kladu literarizovaným osobním deníkem, autofikcí.

Rozlišování mezi fikcí a nonfikcí není zbytečné, nebot' má obecnější význam, který směřuje k takovým problémům, které se dotýkají otázek reference, ontologické povahy jednotlivin i celých časoprostorových komplexů nebo kritérií pravdivosti. Takovéto rozlišování však nemusí být vždy očividné, jindy se setkáváme s prolínáním či přímo konfúzí fikce a non-fikce a vice versa. Ruth Ronenová je přesvědčena, že fikční texty ,jsou př́istupné autonomizaci nebo že ji umožňují a že to, co je činí příhodné pro kulturní autonomizaci, jsou specifické způsoby organizace projevující se ve fikčních světech." (Ronenová 2006, s. 25) Budeme-li vycházet z Doleželových teoretických premis, potom tyto ,specifické způsoby organizace projevující se ve fikčních světech" jsou manifestovány, respektive generovány textovou strukturou. Před její realizací neexistují, tak jako neexistuje fikční svět před svojí formulací. Opět připomínáme, že tato konstatování vychází z Doleželovy teorie literární fikčnosti a že nemusí být obecně takto vždy přjímány (viz třebas Pavel 2012). Jak jsme ovšem viděli výše, bude nezbytné uvažovat rozsáhlejší textové struktury, než jakými jsou pouhé odstavce, popř́ípadě celé kapitoly, $\mathrm{z}$ nichž takováto strukturní distinkce projevující se $\mathrm{v}$ důsledku existence nebo neexistence fikce nemusí být zjevná.
Ačkoli s tvrzením Ronenové souhlasíme, přesto je možné se setkat s takovými texty, ve kterých se mísí odlišné způsoby organizace textu, které jednou odpovídají non-fikci, jindy silně tendují k fikčnosti. Rozlišování mezi fikcí a non-fikcí se tedy nemusí týkat výhradně izolovaných textů, u kterých určujeme jejich žánrovou povahu, ale též společného textu, v rámci něhož jsou různými způsoby realizovány demarkační linie. Společně se španělským teoretikem Félixem Martínez-Bonatim jsme přesvědčeni, že umělecká fikce je ve všech svých oblastech stejně fikční; jinými slovy, že v rámci umělecké fikce nejsou některé výroky nebo entity čistě fikční a jiné o něco méně anebo vůbec, nebot' mají korelát v reálné dimenzi ${ }^{9}$ (viz Martínez-Bonati 2017, s. 103). Je tedy otázkou, zda jsou takové konfúzní či osmotické texty, ve kterých nalézáme podíly faktičnosti a fikčnosti, dokumenty anebo uměleckými texty produkujícími fikční světy. To je i problém některých textů ze souborů vzpomínek Ignáta Herrmanna.

\section{3.}

Vrat'me se ještě k našim čtyřem ukázkám a pokusme se zjistit, zda $\mathrm{v}$ nich přece jen nenajdeme nějaké signály, které by nám na tomto materiálu dovolily uvažovat o rozdílech mezi fikcí a non-fikcí. U první a třetí ukázky jsme konstatovali, že vypravěč nebo autor se obrací př́mo na čtenáře tím, že $\mathrm{k}$ němu explicitně odkazuje (OČ). V obou př́padech se jedná o narativní strategii, která má vést $\mathrm{k}$ upoutání pozornosti na to, co bude $\mathrm{v}$ textu následovat. $\mathrm{V}$ př́padě Nerudovy povídky je ovšem tím, co následuje, příběh dvou mužů zasazený do fikčního světa, zatímco u Herrmanna literarizovaná vzpomínka na masopustní období, tedy nikoli fikční příběh, ale svého druhu kulturně historický narativizovaný výklad. Jinými slovy, jestliže Nerudův vypravěč vybízí čtenáře $\mathrm{k}$ vyslechnutí příběhu a $\mathrm{k}$ tomu, aby obrazně řečeno vstoupil do fikčního světa tohoto př́běhu, Herrmann jako autor

\footnotetext{
${ }^{9}$ Fikční korelát může být od svého nonfikčního protějšku takříkajíc různě vzdálen. Kupř́kladu v postmoderní próze může být slabá míra této distinkce jedním $\mathrm{z}$ uměleckých postupů.
} 
vzpomínky sice rovněž upoutává čtenářovu pozornost, avšak odkazuje ke společně sdílenému ontologickému prostoru, kterým je nonfikční Praha. Otázkou ovšem je, co zodpovídá za fikční status Nerudovy lokace a non-fikční stus lokace Herrmannovy v uvedených ukázkách 1 a 3 . Nerudův vypravěč rovněž odkazuje ke společně sdílenému zkušenostnímu rámci, jenž byl shodný pro autora a jeho čtenáře. Odhlédneme-li od paratextu, potom je to především narativní koncentrace na př́běh obou pánů, která s sebou nese i další podstatné aspekty, na kterých se zakládá autonomie fikční ontologie a kterými jsou narativně performované časoprostorové kvality či axiologické paradigma zobrazeného světa.

U Herrmanna je čtenář autorem bezprostředně naváděn na vlastní téma (TM) vzpomínky, kterým jsou masopustní ostatky. V následujících částech textu Herrmann rozebírá, co bylo staropražské masopustní veselí, co vše jej před mnoha lety doprovázelo. To, co v takovémto typu vyprávění dominuje, je především funkce poznávací. Autor čtenáři zprostředkovává v prvé řadě faktické poznatky o tématu, bez ohledu na to, nakolik jsou ve skutečnosti zkresleny autorovou pamětí. Narativní prvky plní kohezivně koherentní funkci v rámci textu nadřazenému typu deskripce; jsou především využity k jakémusi plynulému přemostění mezi deskriptivními částmi. To se děje bud'to zpětným odkazováním $\mathrm{k}$ hlavnímu tématu nebo jeho derivací (d), která může být textově-syntakticky realizována parataxí (p), jako je tomu v následující ukázce:

$$
\text { TM A }
$$

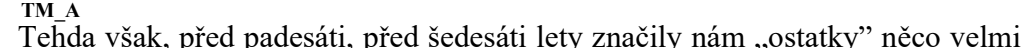
veselého a zvláště horlivé mládeži školní velmi vítaného. Bylyt' to „ostatky masopustní", poslední dva dny v masopustě, pondělí a úterý před

Popeleční středou, a my1 vzorní školáci proto jsme se na ně tolik těšivali, že jsme na ten ostatkový úterek dostávali „fraj”, jak nám pan učitel vždy oznamoval. [...] Méně př́ijemný nám byl doslov páně učitelův..

$[\ldots]$

Tohle připomenutí nám vždy poněkud zkalilo pomyšlení na zítřejší „,fraj”. [...] $[P]$ ozejtři byla Popeleční stř̌eda, kdy vlastně zas nebyla žádná škola, nýbrž jen rānní kostel, trochu delší snad než jindy. Po službách božích totiž nám nám velebný pán uděloval popelec.

[...] (TM)

TM 3

Na samý konec masopustu nezbyl nikdy žádný vznešenější bál.

$[\ldots]$ (TM_A)

TM 4

Na masopustní ostatky měla také pražská ulice své maškarády, bez vstupného a bez nákladných příprav. Dávno to podívání zaniklo.

Byl to Bakchus, Bachus, ale Praha všeobecně ř́kala Bakus (1926, 155-158). ${ }^{10}$

Předchozí ukázku lze schematicky rozepsat následovně:

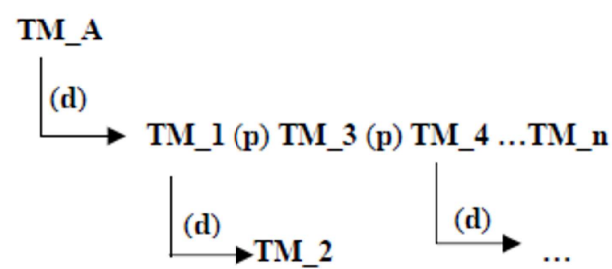

Text vzpomínky je segmentován do několika tematických částí, které jsou de facto vyjmenovány $\mathrm{v}$ podnadpisech každé $\mathrm{z}$ kapitol souboru Před padesáti lety. Rovněž není neobvyklé, pokud je tento model realizován přes hranici jednoho textu, tj. zasahuje do dvou či více formálně oddělených vzpomínek. Tato skutečnost nejenže nenarušuje žánr vzpomínky, ale naopak jej posiluje s tím, že upozorňuje na kontinualitu vzpomínání, na její nepřetržitost, čímž je na druhé straně evokována koherence těchto vzpomínky a v důsledku i jejich relevance, nebot' tímto kompozičním postupem Herrmann signalizuje, že obsahy jeho vzpomínek nejsou pouze náhodnými výjevy autorovy mysli, ale spolehlivým svědectvím. Současně tato technika zaručuje konektivitu mezi jednotlivými texty vzpomínek, které byly původně od roku 1921 vydávány samostatně na pokračování v Národních listech.

V př́ípadě ukázky z Nerudovy povídky je narativní strategie a především intence přece jen jiná. I zde bychom ve shodě s analogií s před-

\footnotetext{
${ }^{10}$ TM_A = hlavní téma.
} 
chozím př́kladem zpočátku mohli uvažovat tak, že vypravěč vlastně neodkazuje k fikčním entitám, ale ke skutečným jevům, a že se vlastně jedná rovněž o vzpomínku na společně sdílený svět a priori, tak jako u Herrmanna. Jestliže u Herrmanna je tímto světem a priori svět kdysi skutečné, avšak dnes již zaniklé Prahy, na kterou si spolu s autorem pamatují již jen starší čtenáři, u Nerudy je tomu vlastně podobně. Čtenáŕi, tak jako autor velmi dobře znali „malostranský hostinec U Štajniců". Je tedy Nerudův text podobným dokumentem kdysi skutečného, dnes již zaniklého světa, jako je tomu v prŕípadě Herrmanna? V takovémto postupu nám ovšem brání nejen paratext, ale rovněž indicie, které vyplývají z narativní strategie realizované v Nerudově povídce.

Podíváme-li se nyní na tento text prizmatem předchozího textu a jeho analýzy, potom vidíme, že na rozdíl od Herrmannovy vzpomínky není v Nerudově povídce hostinec U Štajniců skutečným hlavním tématem tak, jako jím byl staropražský masopust. V Nerudově povídce je zmínka o hostinci proto, aby mohlo dojít k prostorové (a později i časové) lokalizaci vlastního děje. Tento komponent tedy slouží jako iniciální indexace postupně budovaného fikčního prostoru, respektive fikční topografie, a to ve finále bez ohledu na skutečnost, že v Nerudově současnosti hostinec U Štajniců skutečně existoval a nacházel se poblíž Mostecké věže. Co o této fikční subsumaci reálného korelátu rozhoduje, je teprve až širší kontext narativní strategie. Po deskriptivní pasáži, která je komponována do dvou typologických segmentů (A, B), dochází ve vypravování k časovému určení příběhu, tj. do doby „,před lety”, kdy byl vypravěč malým chlapcem. Důležité je ovšem to, že vypravěč přechází $\mathrm{k}$ dalšímu tematickému segmentu, kterým již není samotný hostinec, ale jeho společnost, a navíc společnost specifická, konkrétně společnost dvou postav, které jsou ve výsledku finálním předmětem vyprávění. Na rozdíl od struktury Herrmannova textu zde potom nedochází k derivaci ústředního tématu, ke kterému by se derivované části funkčně vztahovaly tak, že jej rozvíjí a informačně obohacují, ale skrze narativní strategii k postupnému zanořování do př́běhu a spolu s tím k budování stále autonomnějšího fikčního světa pánů Ry šánk a a Schlegla (TM_3). Toto je ústřední motivací a konečným cílem vypravěčovy aktivity, tedy vyprávět událost konfliktu mezi oběma protagonisty. ${ }^{11}$ Graficky znázorněno, dostáváme následující schéma:

TM

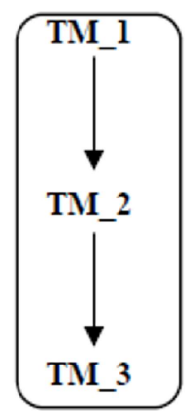

Také zde je patrné, že tématem vypravěčova vypovídání se de facto ve výsledku stává celý vyprávěný svět $(\boldsymbol{T M})$, avšak na rozdíl od Herrmanna se $\mathrm{v}$ tomto př́ipadě utváří fikční svět příběhu pánů Ryšánka

\footnotetext{
${ }^{11}$ Podobný postup, avšak v obráceném pořadí, použil vypravěč v první kapitole povídky Týden v tichém domě, kde „zanoření” do fikčního světa probíhá od postupného rozeznávání jednotlivin, které jsou navíc sdíleně (tj. vypravěčem a čtenářem) reflektovány skrze jednotlivé smysly: „Cítíme, že jsme v místnosti zcela uzavřené. Čirá, hluboká kolem nás tma, ani nejmenší skulinou nevniká odnikud šero; všude jen tma taková, v níž domníváme-li se přec na okamžik míti něco světlého před očima, je to pouze rudý kruh vlastní naší myšlenky.

Napnutí smyslové pozorují i nejdrobnější známky života. Čich náš zvěstuje nám, že místnost naplněna je mastným jakýms vzduchem, sprostou směsicí výparů. Je nám hned, jako bychom hlavně cítili smrkové nebo jedlové dříví, hned zas jakoby lůj a sádlo, a zas jakoby suché švestky, kmín, ba i kořalku, česnek atd. Sluchu se dotýká tykot hodin. Musí to být staré nástěnní hodiny s dlouhým kývadlem, na jehož konci tenký plechový a zajisté že trochu zkřivený kruh; někdyt' se kývadlo $\mathrm{v}$ jednozvučné své povídačce zakoktne a kruh se lehýnce otřese. I to zakoktnutí opakuje se v pravidelných rozměrech a stává se jednozvučným" (Neruda 1966, s. 7).
} 
a Šlégla coby jedinečně, individuálně konfigurovaný prostor fikčně konkrétních situací a událostí, jež existují výhradně v tomto fikčním světě. Tato strategie Nerudova vypravěče současně iniciuje vědomí svrchované konstruovanosti vyprávěného světa, čímž současně dochází k jeho ontologické indexaci (tzv. sekundární ontologie). Její podstatou je odlišení fikčního světa od světa reálného, aktuálního či světů možných. Spolu s narativním zanořováním do příběhu a ruku $\mathrm{v}$ ruce $\mathrm{s}$ konfigurací diskrétního časoprostoru př́iběhu začíná působit dostředivá síla sekundární ontologie konstruova ného fikčního s v ěta, která na sebe poutá veškerou pozornost a odvádí od skutečností, jež jsou za jejími hranicemi. ${ }^{12}$

Podíváme-li se na ukázky 3 a 4, potom se zdá, že zde nemáme konkrétnější atributy, jež by nás navedly k tomu, abychom se na jejich základě pokusili oba texty klasifikovat do jedné z námi uvažovaných kategorií - fikce nebo non-fikce. Jeden z rysů bychom však přece mohli uvést. Je jím vlastní jméno v Nerudově povídce. Konkrétní postava pana Rybáře je pak centrálním tématem povídky, jejíž narativní osnovu (plot) tvoří události týkající se právě této postavy. V Herrmannově vzpomínce postava jméno nemá; jedná se o jakéhosi „vrchního radu”, kterých v tehdejší Praze bývalo několik. A přestože

${ }^{12}$ To má své logicko-modální konsekvence, projevující se v otázce pravdivosti a ověřitelnosti možným odkazem $\mathrm{k}$ referenčnímu statusu jevu anebo $\mathrm{v}$ porušení konzistentní logiky, která platí v reálných či možných světech.

Srov. k tomuto: ,[S]uspendování logických zákonů připojením operátoru fikčnosti se stalo široce uplatňovaným řešením. Např́klad Lewis [autorka citace odkazuje ke studii Davida Lewise Truth in Fiction, která vyšla v roce 1978 v časopise American Philosophical Quarterly - pozn. R.Z.] popisuje operátor fikčnosti jako,intensionální operátor, který můžeme analyzovat jako omezený univerzální kvantifikátor (restricted universal quantifier) možných světů'. Jinými slovy, má-li nějaké tvrzení předznamenání ,ve fikci $\mathrm{f}(\mathrm{p})^{‘}$, pak pravdivost dané fikční propozice (p) je uzavřena implikací fikčního operátoru (f), která omezuje inference vyvozované z takových tvrzení Podobně Castańeda [autorka citace odkazuje ke studii Hectora-Neri Castańedy Fiction and Reality: Their Fundamental Connections, která vyšla v roce 1979 v časopise Poetics - pozn. R.Z.] popisuje rozdíl mezi větou v novinách a větou v literárním textu jako odlišnost operátoru, v jehož dosahu věta operuje" (Ronenová 2006, s. 49). jej Herrmann popisuje i charakterizuje jeho osobnost, modeluje především obecný typ staropražské figurky; podobně postupuje i v dalších svých vzpomínkových textech, využívaje výše popsaného principu derivace. Na této situaci nic nemění ani to, že v jiných svých vzpomínkách Herrmann své postavy častěji pojmenovává. ${ }^{13}$ Toto pojmenování může být neúplné, jako je tomu v př́padě vzpomínky Starý švejda Václav (podrobněji viz oddíl 4) anebo úplné. Herrmann vždy, byt' s různou intenzitou odstupu od svých postav, modeluje obecnější typ odpovídající své době. Mohli bychom namítnout, že také Neruda ve svých povídkách odkazuje k takovému obecnému typu, avšak rozdíl zde spočívá $\mathrm{v}$ tom, že u Nerudy se tento obecný typ schovává za literární postavu, která existuje a priori jako uměleckým vyprávěním stvořená fikční postava (tř̌ebas i s reálným korelátem), zatímco u Herrmanna je tomu a posteriori. ${ }^{14}$ Herrmannovy beletrizované vzpomínky mají v konečné platnosti odkazovat k non-fikčnímu světu, tj. ke světu kdysi reálnému, který se zdaleka nevyčerpává textem, který $\mathrm{k}$ němu odkazuje. ${ }^{15} \mathrm{~V}$ př́ípadě Nerudovy povídky se v konečném důsledku neodkazuje ke skutečnému časoprostoru a událostem kdysi reálného světa, jehož byl autor součástí,

${ }^{13}$ To je typické zejména pro soubor Bodři Pražané, avšak konkrétní jména postav se objevují také v dalších Herrmannových vzpomínkových knihách. Platí ovšem, že se jedná o typy dávno zaniklého, avšak kdysi skutečného světa staré Prahy. Nerudovy postavy jsou oproti tomu nejen zřetelněji individualizovány, ale chápou se jako konkrétní fikční fakt.

${ }^{14}$ Srov. následující ukázku, kde lze identifikovat odkazy k mimotextové skutečnosti (předloze), které jsme vyznačili podtržením, a k obecně sdílenému povědomí: „Dílna Heidelbergova byla tehda ve starém domě ,U Bílého kohouta' na Židovské zahradě (nyní ulice Vladislavova). Nový dům na jeho místě zbudoval si Václav Frič, proslulý a znamenitý propagátor přírodnin. [...] Votoček, jejž před půlstoletím znala celá Praha pode jménem Jindra a na jehož osobu byla zavěšena přezdívka ,Deka ${ }^{\boldsymbol{c}}$, vyžadoval by zvláštní kapitoly. Náležel ke zjevům, jejichž typ již vymřel. [...] Jmění se nedopracoval ani Heidelberg, ani Votoček, ale Heidelberg měl četnou rodinu, Votoček tuším žádné" (Herrmann 1924, s. 28-29).

${ }^{15}$ Zřetelně do dokládají i následující Herrmannova slova v předmluvě k prvnímu dílu jeho vzpomínkového cyklu Před padesáti lety: ,Jsem si předobře vědom, kterak 
tzn. k Nerudově historické Malé Straně, ale k fikční Malé Straně, která svými konkrétními fikčními entitami (postavami a místy) vytváří fikční koreláty k jevům non-fikčním. A opět můžeme konstatovat, že na této skutečnosti nic nemění ani to, že byl Neruda inspirován reálným staropražským prostředím. Samozřejmě jiná bude otázka reálné recepce, kdy čtenář, jenž není literárněvědným analytikem, může Nerudovo vyprávění číst jako svého druhu dokumentární text.

Rozbor a zejména vyhodnocení uvedených ukázek v konečném důsledku samozřejmě probíhal na pozadí celých kontextů, které rozhodují o funkčním zapojení všech částí textu. Pokud bychom nebrali $\mathrm{v}$ úvahu širší kontexty, které se sestávají z úplných dílčích textů (celých povídek nebo vzpomínek), jejich souborů (Nerudova kniha povídek oproti Herrmannovým vzpomínkovým knihám), obecného povědomí o povaze fikčních narativů apod., potom by zřejmě nebyl žádný vážnější důvod pro to, aby námi vybrané Nerudovy iniciální pasáže jeho povídek nemohly figurovat jako non-fikční text, např́klad jako vzpomínka a naopak, tj. Herrmannovy vstupní části jeho vzpomínek jako úvod pro nějakou povídku. Ve chvíli, kdy ovšem začíná působit specifická strukturace celého textu a kontextů jako projev organizování jednotlivých segmentů autonomním vypravěčem, dochází k vyvolání efektu silné dostředivosti do vyprávěného světa, který je tímto navíc indexován jako ontologicky odlišný od světa reálného anebo možného. Této dostř̌edivé síle jsou podřízeny veškeré segmenty vyprávění. V Nerudově povídce se tak postupně „noříme” do fikčního

jsou tyto drobné vzpomínky mezerovité a že v nich není žádného systému. Ale vždyt' nepíšu žádné dějiny! Pokusil jsem se prostě vylíčiti, kterak v Praze ledacos bývalo, jak se $\mathrm{v}$ ní kdysi žilo, kterak se v ní mluvívalo atd. Jsou to jen pouhé drobty toho někdejšího malého zapadlého života pražského. Kdyby nás psalo deset a dvacet, nevyčerpali bychom vše, co činilo Prahu Prahou a čím nám všem její někdejší život byl tak milý. Vždyt' skoro každá její čtvrt žila životem svým, vlastním a zvláštním, skoro každá ulice měla své osobité zjevy a svou kroniku. A tak bud'tež tyto mé kapitoly pojímány jen jako důvěrné vyprávění ve chvílích soumraku, v černé hodince" (Herrmann 1924, s. 7-8) světa této povídky. ${ }^{16}$ Jeho gravitační síla pohlcuje vše, co se ocitá $\mathrm{v}$ jejím dosahu. $\mathrm{V}$ tomto případě je jí kromě čtenáře zasažen i zmíněný hostinec U Štajniců, který se nachází na kritické (zlomové) hranici této gravitace, na jakémsi pomyslném horizontu událostí, ${ }^{17} \mathrm{kdy}$ přechází ze světa non-fikčního do literární fikce, čímž proměňuje svoji ontologickou platnost.

Na dosavadních ukázkách jsme mohli demonstrovat pouze „slabé” rozdíly mezi fikčním a nonfikčním statusem textu. Zdůraznili jsme, že rozhodující úlohu má teprve širší kontext. Bez jeho znalosti bychom mnohdy nedokázali určit, o jaký text či jeho součást se jedná. ${ }^{18}$ Teprve širší kontext, tj. komplexnější strukturní systém je schopen (spolu)definovat, zda text bude mít svůj referent ve světě skutečném či možném, anebo takový referent bude postrádat. Ve druhém př́ípadě uvažu-

${ }^{16}$ Srov.: „Skutečnost, že fikčnost nějakého světa operuje nad všemi doménami, jež tento svět konstituují, musí ovlivnit jeho vnitřní strukturu” (Ronenová 2006, s. 124; srov. i dále Ronenová 2006, s. 168). K uvedenému tvrzení dodejme, že kromě zjevné determinace struktury textu, jejímž výsledkem může být příznaková struktura narativní fikce, dochází také k podřízení se této doméně těch struktur, které nemusí být z hlediska opozice fikce-nonfikce jednoznačně symptomatické. To jsme viděli také na předchozích ukázkách.

Přiřazení atributu fikčnosti určitému textu nemusí záviset výhradně na strukturních rysech a systémových markrech textů. Jak upozorňuje Ronenová: „Fikčnost textu je typ vztahu mezi pisatelem a čtenářem, jenž se odráží ve světě, který tento text projektuje. [...] Poněvadž fikčnost textů nelze a priori identifikovat s nějakým konkrétním souborem textových rysů nebo se stabilně danou skupinou textů, cesta je otevřená pro pragmatickou definici fikčnosti, která má vzít v úvahu celistvý systém konvencí výstavby světů, kulturních přesvědčení a čtenářských procedur" (Ronenová 2006, s. 104, 106).

${ }^{17}$ Srov. napřr. Ronenová 2006, s. 126-127, 145 a jinde; Martínez-Bonati 2017, s. $97,103-104$.

${ }^{18}$ Jiným př́íkladem jsou takové typy iniciálních segmentů, které explicitně signalizují, že půjde o fikční vyprávění. Jedná se o užití frází typu: bylo nebylo, za devatero horami, budu vám vyprávět př́iběh apod. 
jeme rovněž o fikčních světech, ${ }^{19}$ jejichž entity jsou schopny vytvářet maximálně ontologickou korelaci k nonfikčním protějškům. Současně jsme uvedli, že ve chvíli, kdy je „rozhodnuto” o statusu textu, vstupují všechny jeho segmenty do jím definované ontologické třídy. Jinými slovy, ocitají se pod vlivem silového působení dominantní strukturní organizace zodpovědné za ontologicko-modální povahu reprezentovaného světa. Vliv této dostředivé tendence jsme v př́ipadě Nerudových textı̊ mohli na povrchové rovině textu výrazněji pozorovat v první ukázce, zatímco ve druhé byla sama o sobě mnohem slabší.

Uvedené př́iklady nám ukázaly dvě důležité vlastnosti fikčních a nonfikčních světů, $\mathrm{z}$ nichž první spočívá v důležité otázce směřující ke konstrukčním vlastnostem textu, druhá se dotýká hranic mezi oběma světy. V př́ípadě první ukázky jsme mohli sledovat, že narativní konstruování fikčního světa se projevuje ve způsobu konstrukčního chápání iniciálního segmentu, což platí i v př́ípadě Herrmannovy vzpomínky na masopustní ostatky, kde iniciální segment se nestává součástí vyprávění fikčního příběhu, ale vzpomínky na kdys skutečnou událost. ${ }^{20}$ Hranice, které jsou stanoveny mezi fikcí a nonfikcí jsou fluidní a osmotické. Jednou je Praha součástí vzpomínky a ožívá jako skutečný anebo možný prostor, jindy se transformuje do fikční podoby, která se výrazněji osamostatňuje od svého non-fikčního protějšku. V uvedených ukázkách jsou ovšem obě ontologické dimenze spolehlivě odlišeny paratextovou informací. V př́padě Nerudových textů tak předem víme, že se jedná o literární dílo, u Herrmanna naopak primárně o beletrizované vzpomínky. Hranice se zdají být jednoznačně definovány.

\footnotetext{
${ }^{19}$ Nemusí se však jednat pouze o uměleckou fikci, referent mohou postrádat například výpovědi halucinačního blouznění, živého snění apod.

${ }^{20}$ Srov.: „Každá fikční oblast má svůj jedinečný způsob organizace. Fikční oblast entit je organizována rétorickými způsoby definování, které potvrzují autonomii a soběstačnost konstruovaného světa. V oblasti entit stejně jako v ostatních fikčních oblastech jsou způsoby organizace specifické pro fikci aktivovány v nějakém kontextu" (Ronenová 2006, s. 168)
}

Herrmann své vzpomínky na starou Prahu a její obyvatele usiloval psát co nejvěrohodněji. Není proto neobvyklé, že v průběhu vyprávění o místech a událostech dávno minulých učiní autor menší digresi, ve které reflektuje intenci svého psaní:

Nesmím se dát unésti žádnou vzpomínkovou fantazií (a bylo napsáno dosti „vzpomínek”, na kterých větší podíl než pouhá skutečnost měla živá a nekrocená fantazie), a jestliže se kde bezděky dopustím omylu, může takový omyl býti zavčas opraven. Fantazie budiž odkázána do povídek a románů (Herrmann 1926, s. 98)

Herrmannova snaha zůstat věrný historickému faktu sice mohla být zachována - dnes budeme jen obtížně rekonstruovat, zda autorovy vzpomínky odpovídají historické realitě - avšak jeho úsilí nepřekračovat hranice mezi fakticitou a fikcí se z dnešního úhlu pohledu mohou jevit mnohem problematičtěji. Umělecká fikce nemusí nutně pracovat s vymyšlenými entitami, ale zcela dobře, ba mnohem důmyslněji operuje s koreláty non-fikčních jevů (viz výše). Jestliže jsme až doposud sledovali techniky výstavby žánrově separovaných částí textů z hlediska příznaků určujících opozitnost mezi fakticitou-fikčností, potom $\mathrm{v}$ následující části výkladu se zaměříme na takové jevy, které jsou př́kladem osmózy těchto dvou ontologických polarit.

Mezi Herrmannovými vzpomínkovými texty najdeme i takové, které jsou z hlediska jednoznačné polarity mezi fikcí a non-fikcí pozoruhodné tím, že hranice mezi oběma mody se nachází v rámci společného textu. Jsme si vědomi, že tímto tvrzením se de facto dostáváme do paradoxní situace, nebot', jak jsme konstatovali odkazem k názoru Martínez-Bonatiho, pokládáme fikci za ontologicky homogenní di-

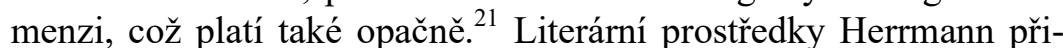
rozeně využívá k zesílení evokace zanikajícího staropražského světa; konkrétně se to týká dialogických pasáží a scénických digresí. Obvykle bývá mezi vlastním segmentem autorovy vyprávěné vzpomínky

${ }^{21} \mathrm{~V}$ rámci fikce lze rovněž zvažovat odlišné ontologické statusy podle toho, ke které dimenzi dané prvky náleží. To je př́klad intradiegetického vyprávění, ale třebas i retrospektivy nebo onirických segmentů př́běhu. Vzhledem k nonfikční oblasti však veškeré takovéto kvality budou mít rámcově fikční status. 
a segmentem scénickým plynulý přechod, takže scénická část, jakýsi malý výjev ze staropražského života, slouží pouze jako součást popisu kdysi typických reálných situací odehrávajících se například v hokynářství, ve staropražských ulicích a na nárožích apod. Samotné využití literárních postupů (techné) samozrrejmě ještě nemusí problematizovat hranici mezi fikcí a nonfikcí. Většinou jsou tyto literarizované části Herrmannových vzpomínek plně integrovány do nonfikčního textu, který tímto oživují a ozvláštňují, což byl jistě autorův záměr, jak učinit své vzpomínání poutavější.

Mezi Herrmannovými vzpomínkovými texty však najdeme i takové, které disponují takovými rupturami, které již nabývají schopnosti odlišovat vyprávěné jednou jako dokument, osobní vzpomínku, podruhé jako akt fikcionalizace. V takovýchto př́ikladech můžeme dokonce hovořit o ,vpádu" fikčnosti do non-fikce, aniž by nutně muselo dojít k přepnutí do čiré fantazijní fabulace. Jinými slovy, látka zůstává stejná, proměňuje se však způsob jejího zpracování, respektive reprezentace. Abychom tento jev demonstrovali, zvolili jsme konkrétní vzpomínkový text ze souboru Bodři Pražané nazvaný Starý švejda Václav. ${ }^{22}$ Vedle souboru Před padesáti lety se v této knize Herrmann výrazněji soustředil na vykreslení mizejících staropražských lidských typů a také zde se řídí pravidlem zůstat pokud možno co nejvíce věrný skutečnosti.

Jmenovaný vzpomínkový text publikovaný v souboru Bodři Pražané byl autorem zpočátku publikován v časopise Švanda Dudák v roce 1887 . Původní časopisecká verze obsahuje vzpomínkové vyprávění o Václavově fyziognomii, jeho zvláštních osobnostních rysech, zvycích nebo způsobu, jakým vykonával své povolání. Rovněž i zde vidíme autorovu snahu přiblížit a zejména oživit postavu starého Václava například pomocí zapojování prrímé řeči. V roce 1892 se Herrmann k tomuto textu vrátil a výrazně jej rozšiŕil pro finální knižní vydání. Od předchozí části tento segment odlišuje výraznější subjek-

${ }^{22}$ Jednotlivé texty původně vznikaly od druhé poloviny 80 . let 19 . století jako články pro humoristický časopis Švanda Dudák. tivizace vzpomínky, což se projevuje především prolongací scénických segmentů a dialogických pasáží, které signalizují autorovo vybavování si ryze osobních, až soukromých vzpomínek. Podobně jako v jiných Herrmannových textech, ve kterých je využito takovýchto literarizovaných postupů, se ještě nutně nejedná o jev, o kterém jsme mluvili výše, totiž o fikcionalizaci vyprávěného, ačkoli zmíněná prolongace těchto literarizovaných pasáží $\mathrm{k}$ tomuto jevu směřuje. Co však tuto tendenci k fikcionalizaci limituje, je přece jen dostatečně zřejmé subsumování takovýchto scénických a dialogických segmenti̊ do narativu vzpomínky, který má být $\mathrm{v}$ prvé řadě fakticistním narativem.

Herrmannův Starý švejda Václav není složen pouze ze dvou částí, jak napsal autor, ale též z dalších segmentů, které nerozlišuje ani tak časová vzdálenost, ale spíše relativní vzdálenost ontologická. Pro bližší objasnění tohoto tvrzení je nezbytné přistoupit k rozsáhlejším segmentům analyzovaného textu:

[A]

Psal jsem předcházející řádky o starém švejdovi Václavu před pěti lety. Tehdy žil ještě svůj bezradostný život a šoural se po Praze šáravým, šeplavým krokem, všecek rozviklaný, jako by se chtěl zlomit v kolenou, pravým ramenem ku předu, jako vždy. $[\ldots]$

\section{[B]}

„Mco pak to, mpane Herrmann, že prej mě dali'm do novin!”

[A]

Onikal ze starého zvyku, ale jen lidem, k nimž měl zvláštní úctu a důvěru. Ke mně ji měl. Jinak i vykal a říkal „Vašnosti”, ale to byl jeho způsob nejslavnostnější, obřadný.

A tím ,„m” pokouším se naznačiti jeho milé huhňání. Někdy huhňal Václav na počátku slova, někdy na konci.

Již mu byl někdo řekl, že je „sepsán”.

\section{[B]}

„Hněváte se na mne, Václave?”

„Mňo - nehněvám, ale mdostanu za to mněco?" 
[A]

Rozdělil jsem se s ním o honorář. Rozdělil tak, že jemu jsem dal mrzký kov a sobě ponechal „slávu”.

„A'm budou o mně ještě mněco psát?"

Všimlt' si bystře, že článeček byl označen římskou jedničkou, že tedy má něco následovati.

Odpověděl jsem, že hodlám, nebude-li se vůbec hněvat. Václav kývl hlavou na znamení souhlasu a sistým lišáctvím na tváři. Bleskla mu hlavou patrně myšlenka na další účastenství na honoráři (Herrmann 1959, s. 130-131).

Části označené písmenem B náleží k scénickým a dialogickým segmentům, které Herrmann ve svých vzpomínkách často používá. Jejich status z hlediska námi sledované polarity fikce-nonfikce vyplývá z jejich funkční subsumace pod textový rámec vyznačený písmenem A. Jinými slovy, interpretace této a jí podobných pasáźí podléhá ontologickému statusu, který je nastaven rámcem $\mathbf{A}$; tedy jsme oprávněni chápat dialogické pasáže jako situace s referencí, odkazující ke skutečné, historické události, i když se můžeme domnívat, že přesně takto nemusela ve skutečnosti proběhnout. To ovšem není podstatné jako spíše to, že tato technika se snaží evokovat životný projev a vjem kdysi skutečného staropražského světa. Realizace této situace pomocí dialogu a autorovy interpretace její části (viz poslední věta ukázky) ji zásadním způsobem zpřítomňuje a vyvolává efekt, jako bychom byli sami svědky této události, vtahuje nás do dění. To je jistě jeden z př́značných rysů fikce. Jak jsme ovšem uvedli, jako fikci tento segment nejspíš chápat nebudeme. Existují zde totiž hierarchicky nadřazené strukturní rámce disponující především deiktickým časoprostorovým určením, které ve funkční korelaci s paratextem odkazují za hranice textu do světa skutečného, byt' v čase vyprávění již nenávratně destruovaného rozvíjející se moderní epochou 20. století. Pokud bychom parafrázovali výše uvedenou pasáž, mohli bychom si vypomoci tak, že promlouvající subjekt, kterým je autor, nám sděluje: Stalo se tak před mnoha lety, $v$ době mého mládí, kdy jsem přišel do Prahy a zde, na tomto místě vám vyprávím to, co si vybavuji a co se mně samotnému tehdy skutečně přihodilo.
Řekli jsme, že promlouvajícím subjektem je autor, avšak stejně dobře bychom si tuto situaci mohli představit jako literární vyprávění, kdy bychom na místo autora dosadili komentujícího autorského vypravěče. Proč však v tomto príípadě uvažujeme o autorovi, vyplývá z výše uvedeného.

Jestliže $\mathrm{v}$ tomto případě literární postupy neproblematizují vnímání textu stále jako dokumentu a nikoli fikce, v částech následujících za výše uvedenou ukázku polarita mezi dokumentem a uměleckou fikcí narůstá. Je třeba doplnit, že následující část je v textu vzpomínky oddělena od předchozí i následující a tvoří jakýsi samostatný oddíl a kromě postavy Václava nenavazuje na předchozí část:

${ }^{\mathrm{A} N}$ Uplynulo skoro čtvrtstoletí ode dne, kdy jsem za listopadového večera z malého venkovského města přijel do Prahy, abych vstoupil incipint

(nenarativní

segment)

I do učení. Škola mi nelahodila, osud můj byl rozhodnut. Na kupectví s klukem!

Jak mi bylo při prvém vstupu do Prahy, jak na mne padalo veliké město, hrozíc mne zalehnouti, p̊ověděl jsem na jiném místě. Ještě toho večera zastavil se se mnou bratr, který mne na nádraží očekával, v knihkupectví strýcově, aby požádal sluhu závodu strýcova, by zítra ráno přivezl z nádraží kufr, obsahující první můj skrovný majetek. Tím sluhou byl starý švejda Václav. Zdál se mi tehdy již prastarým člověkem; mládí nemá měřítka pro léta „stařec” Václav byl snad něco málo přes čtyřicet let. Ale ovšem těžká práce a nuzácký život vrýval mu léta dvojnásobně ve vychrtlou, kostnatou tvár.

$\longrightarrow$ V/A

Prozatím ubytoval jsem se u bratra, kam Václav $\underline{3}$ hned druhý den dovezl truhlu moji z nádraží. Chvíle, které bylo třeba, aby složil břemeno své a do kteréhosi kouta světnice je uložil, použil starý II švejda ku přátelskému výslechu, prvnímu to „interview”, jemuž jsem byl podroben. Vyptal se na moje stáří, jak dlouho jsem jel do Prahy, kolik nás je doma, kde se budu učit, jak dlouho, co se za to bude platit, atd. A měře moji slabou, chudokrevnou postavu, prohodil maně, že mne „vozík zesíli’”. 
Zachvěl jsem se tehdáž trochu. Již jsem slyšel a tušil, co mi nastává. ${ }^{4}$ Veliké, neznámé město, bludiště spletitých ulic a uliček, nikde známé tváře - a vším tím budeš po léta vláčet vozík od rána do večera...!

Zdálo se, že Václav postřehl moji náhlou skleslost duševní a pronesl několik slov, aby mne utěšil.

„Žádné strachy, pane Ignác,” dodával. „V̌̌ak já se také už natahal té drožky. Všecko na světě má konec a pak z nich bude pán..."

Každé přátelské, prrívětivé slovo bylo balzámem mé rozesmutnělé duši, a poněvadž byl Václav skoro prvním, který ke mně na počátku nového života soucitně promluvil, přilnul jsem $\mathrm{k}$ němu veškerou příchylností mladé, poddajné dětské mysli. Spatřil jsem ho ještě dvakráte, třikráte $\mathrm{v}$ oněch prvních dnech pražských a posledních mé chlapecké svobody - a byl jsem odveden k principálu kupci, kterýž se svými pomocníky a staršími učedníky měl ze mne učiniti člověka pro život.

${ }^{\mathbf{5}}$ Tehdáž ohlašovala se zima tvrdým, studeným, sychravým podzimkem. První dny mého učení byl mi průvodcem nepovědomými končinami pražskými starší učedník, a když jsem nabyl jakéhosi chabého ponětí, kterými směry nutno ubírati se $\mathrm{k}$ nádražím, $\mathrm{k}$ velkokupcům, do některých továren a jiných závodů, s nimiž jsme byli v obchodních stycích, nastupoval jsem další cesty sám - $\mathrm{s}$ vozíkem před sebou.

${ }^{6}$ Byl nevlídný den prosincový. $Z$ rána leskly se na dlažbě zmrazky, později poletoval šedivým vzduchem řídký, suchý sníh, ulicemi fičel ostrý, kousavý vítr. Celý ten den byl jediným soumrakem.

segment) Po obědě vyslali mne, abych odkudsi z Ungeltu nebo z Dlouhé třídy přivezl sud petroleje. S prázdným vozíkem jelo se lehce, ale I zpáteční cesta byla jediným utrpením. Tlačil jsem vozík s těžkým břemenem, hledě úzkostlivě vstříc každému povozu, který moji dráhu křižoval, abych nebyl zajet, a vytáhl jsem tak dvoukolák až na počátek Žitnobranské ulice. Byl jsem v potu vykoupán a kouřilo se ze mne, když jsem dospěl v ta místa. S vynaložením posledních sil rozejel jsem se, abych překonal kopeček, ale údy vypověděly služ-

| bu. Kolena se pode mnou třásla, kola vozíku byla jako přimražena.
| Již jsem jen zápasil, aby mne těžký náklad nesrazil zpět, aby mne Událost | vozík nestrhl a nesjel mi někam po svahu - kam až, nedovedl jsem narativní usoudit

segment) Stál jsem bez rady a pomoci a chápalo se mne veškeré zoufalství, jakému jen může propadnouti čtrnáctiletý chlapec. Každý sval třásl se dlouhým přepínáním, ruce se chvěly a to chvění přecházelo

I na vozík, jejž jsem s největším namáháním udržoval na hrbolaté, | stoupající dlažbě. Tyto ruce prostonávaly již ode dvou neděl první kupeckou nemoc. Byly naběhlé, červené až do fialova, prsty jako skleničky, kůže na kloubech pukala a bolavěla. Zabodával jsem nohy do štěrbin dlažby, aby mne vůz nesrazil, ale nohy mi ujižděly. Bylot' zatím napadlo sněhu na prst, dlažba byla kluzká.

| Nikdo nedbal malého kupeckého nádeníka. Dospělí kráčeli nevšímavě dále, výrostkové pak, kteří se nade mnou zastavili, častovali mne jízlivými úšklebky.

| „Hyjé! balíku kupecký! Vid’! Kdyby to tak jezdilo samo a ty si na to mohl sednout!".

Vítr fičel, já však necítil jeho šlehů; hořel jsem všecek těžkým | zápolením a studem nad svojí malomocí. Lidé se rojili kolem, ale nerozeznával jsem již jednotlivé postavy; horké slzy lítosti a zlosti zaplavovaly mi zraky. Již již ochaboval jsem k padnutí. Již jsem viděl, kterak klesám a kterak se vozík řítí přese mne...

\section{Tu v tísni největší zazněl vedle mne hlas:}

„Pozor! Zabrat, pane Ignác!”

| ${ }^{8}$ A čísi ruka dotkla se mé pravice, chápajíc se prríčného řemenu, jímž byl spjat žebřík vozíku. Jen jako pudem zabral jsem, opřel se I posledně, a vozík jel vzhưru ulicí. Se mnou zároveň zabraly jiné dvě | nohy, zatlačily jiné dvě ruce - starého švejdy Václava. Kráčel cestou, všiml si mého zápasu, poznal mne a přispěl na pomoc. A je-

| ho přispěním vytlačil jsem konečně vozík až $\mathrm{k}$ cíli, ke kupeckému krámu proti Krakovské ulici.

Byl bych mu zlíbal v té chvíli staré, svraštělé ruce a umiňoval jsem si, že nikdy nezapomenu na tento jeho samaritánský skutek. ra. Přivezli mne tam v drožce, obaleného peřinami a houněmi, a po- 

matuji už, jak dlouho jsem stonal, ale pamatuji, kterak mne v prázdných svých chvílích ošetřoval starý švejda Václav. Ležel jsem doma skoro po celý den sám, bratr musil seděti v advokátní kancelár̆i

A v těchto truchlivých dnech, kdy jsem stonal vzdálen matky a zbaven její péče, uzavíral jsem upř́mné přátelství se starým knihkupeckým sluhou, se švejdou Václavem, a přátelství naše nepominulo... (s. 132-135). ${ }^{23}$

Ukázka je kompletním a relativně samostatným oddílem, který je vložen do jinak vzpomínkového textu o knihařském pomocníku Václavovi. Mohli bychom ji tedy chápat jako součást této vzpomínky a dále ji neproblematizovat, avšak zpo̊sob, jakým je konstruována, přece jen vybočuje $z$ dosavadního kontextu. Jedná se de facto o další zpracování tématu starého švejdy Václava, a to stále v rámci společné kapitoly. Co přimělo autora $\mathrm{k}$ takové strategii, byla zřejmě snaha tuto postavu co možná nejvýrazněji a nejživěji evokovat. Za tímto účelem postoupil za stávající hranice literarizovaných pamětí směrem k fikcionalizaci, nebot' tato dimenze je schopna poskytnout vyprávěnému patřičnou plasticitu a evokační sílu. ${ }^{24}$ Naším úkolem je nyní objasnit, co tuto fikcionalizaci (nikoli fikčnost!) zakládá a v čem se odlišuje od předchozích př́ípadů.

Pomineme-li paratext, který nám v tuto chvíli nepomůže, nebot' zůstává stejný, což znamená, že uvedenou ukázku vřazuje pod status non-fikce, jsme odkázání na textové komponenty a jejich strukturněsémantické vztahy. Začneme-li rozbor od začátku, nabízí se otázka, kdo promlouvá. Je jím autor (Ignát Herrmann) anebo literární vypravěč? Zdá se, že odpověd' je nasnadě, jako tomu bylo v předchozích př́padech, avšak situace je komplikovanější. Připsat promluvu autorovi (A) nás opravňuje paratext, jakož i odkaz $\mathrm{k}$ předchozímu kon-

\footnotetext{
${ }^{23} \mathbf{A}=$ autor, $\mathbf{V}=$ vypravěč.

${ }^{24}$ Obě kvality souvisí s výraznou funkcí takového typu narativu, tj. narativu s performativní funkcí.
}

textu vzpomínky (1). Avšak tyto komponenty postupně ztrácí dominantní funkci jakýchsi ontologických indexů, které by vyprávěné připsaly nonfikční dimenzi ,,pouhé” autorovy vzpomínky. Toto oslabení způsobuje jednak výrazně subjektivní vypravěč a současně jím konstruovaná konkrétní časoprostorová lokace. Významně subjektivní modus narátora je signalizován zejména poloprrímou řečí (4). Tato narativní strategie vyvazuje dřivější status vypovídajícího subjektu $\mathrm{z}$ jeho nocionálně fakticistní věrohodnosti a přepíná jej do sféry já/vypravěče-demiurga a konstruktéra příběhu. Nepřímo pak tento segment determinuje předchozí část textu, která se tímto vyvazuje z hranic čistě fakticistní vzpomínky a tenduje do oblasti fikce (což signalizuje akt narativní performativity, rámování vyprávěného a konstruování imanentní časoprostorové dimenze), aniž by se jí ovšem v konečném důsledku stala.

Samotné působení polopřímé řeči ovšem k vykonání takovéto dostředivé síly (fikcionalizaci) nepostačuje. Důležitá je i konkrétní časoprostorová lokace $(\mathbf{1}, \mathbf{3}, \mathbf{5}, \mathbf{6}, \mathbf{9})$. Její konkrétnost ovšem nespočívá v přesném uvedení místa nebo času, jako tomu je v jiných Herrmannových vzpomínkách, ale ve fikcionální konkretizaci: jeden listopadový večer, druhý den po tomto večeru, o týden později atd. V takovémto „konkrétním” časoprostorovém rámci se lze plně orientovat, nebot' jsou vytyčeny jeho elementární konstitutivní komponenty. Tato orientace je však plně fixována na samotný narativní způsob. Uvedená kritéria rovněž modifikují vypovídající subjekt takovým způsobem, že dovolují dosadit na místo autora $(\mathbf{A})$ vypravěče $(\mathbf{V})$ a chápat text od jeho začátku za vyprávění, které pronáší nikoli autor, ale vypravěč, jenž je v důsledku přece jen odlišný od Herrmanna coby autora.

To potvrzují i další komponenty textu. Jestliže v jiných svých vzpomínkách Herrmann jakožto autor vypráví konkrétní příběhy ze staré Prahy in margine charakteristiky a popisu místa a doby, zde je tomu naopak. Celý text je výrazně epizován. Konstrukce minipř́iběhu je složena ze dvou událostí, které - opět na rozdíl od předchozích vzpomínek - na sebe kauzálně navazují mimo jiné také tím, že neporušují konstruované časoprostorové kontinuum, naopak je upevňují, 
činí je homogenním $(\mathbf{5}, \mathbf{6})$. Indexy fikcionalizace jsou př́ítomné i dále. Výše jsme uvedli, že polopřímá řeč modifikuje vypovídající subjekt $\mathrm{z}$ kategorie autora do kategorie subjektivizovaného vypravěče, kterého bychom mohli označit za vypravěče sice homodiegetického, avšak vyprávějícího $\mathrm{v}$ určitém distančním časovém modu od vyprávěné události (zde 25 let). Subjektivní modus v narativní strategii takového vypravěče je zjevný také $\mathrm{v}$ místech, kde vypráví o vlastní záchraně $\mathrm{z}$ trapné situace $(\mathbf{7}, \mathbf{8})$. Subjektivita je zde implikována vnitřně fokalizovaným narativním segmentem (v Genettově smyslu), jehož součástí je prrirozeně kognitivně omezený rozsah vypravěče $(\mathbf{8})$.

Uvedené aspekty, které vytváří strukturně provázaný celek, mají za následek iluzivnost vyprávěného, jež spočívá v tendenci k fikcionalizaci, aniž by ovšem v konečném důsledku došlo k úplnému vplynutí do fikce. Lze je (spolu s dialogy) chápat za jakýsi operátor či iniciátor fikčnosti (viz pozn. 12). Nejzávažnějšími komponentami tohoto operátoru či funkce - nebot' se jedná o složený operátor či funkci jsou: vyprávěcí strategie, jedinečná událost a časoprostorová konkretizace, která působí jako fikcionální index. Ačkoli v Herrmannových vzpomínkách nacházíme různé vyprávěcí strategie připisované autorovi, časoprostorové lokace do období Prahy 70. a 80. let 19. století, přece jen se nejedná o typologicky, a především funkčně zcela analogické postupy. Výrazně subjektivizovaný vypravěč se v tomto prípadě zbavuje břemen solidního svědectví o minulosti, jež připadá autorovi, tj. Ignátu Herrmannovi (neodkazuje k mimotextovým skutečnostem, neujišt'uje čtenáře o tom, že je autorem, který nefabuluje, ale s nezbytnou rétorickou dikcí referuje o skutečných událostech), a mnohem více se soustředí na konstruování vyprávěné události a s ní i časoprostoru, který vzniká $\mathrm{v}$ rámci aktu jeho narace. Navíc tento časoprostor opět není významněji ukotvován $\mathrm{k}$ mimotextovým skutečnostem, a tím pádem ověřován mimotextovou realitou. Nemalou autonomii tomuto fikcionalizovanému mikrosvětu dodává podstatná věc, kterou je akt epizování, jehož produktem jsou konkrétní př́iběhy; konkrétní a homogenní události, jakkoli je jejich rozsah minimální, odehrávající se v dimenzích konstruovaného světa. Na rozdíl od předchozích částí
Herrmannových vzpomínek vykazuje tato a jí podobné rysy př́značné pro literární fikci. Uvedená kritéria realizují jeden z podstatných rysů fikce spočívající v „kontinuit[ě] a homogenit[ě] fikčního diskursu a samého fikčního světa" (Bonati-Martínez 2017, s. 103). Událost, ke které dojde v uvedené ukázce, má opět na rozdíl od většiny Herrmannových vzpomínek nejen kauzálně-narativní vyústění, ale též pointu. Neméně důležitý je rovněž odlišný způsob toho, jak jsou jevy nahlíženy ve skutečnosti a ve fikci. K tomuto rozdílu, který se svým způsobem projevuje i ve způsobech konstruování textů, výstižně poznamenal Nicholas Rescher následující:

Skutečnost může být nekonečně složitá, ale je také zcela nezaostřená. Neobsahuje zaměření pozornosti. Př́roda předkládá mnoho věcí dohromady. Její oblíbenou spojkou je ,a', spíše než ,a tak'. Nemá žádnou perspektivu, ale je vše najednou. Spojuje, ale neupřednostňuje. Na rozdíl od lidského oka nebo lidské mysli, skutečnost nemá ohnisko (Rescher 2017, s. 55). ${ }^{25}$

Typologicky odlišný způsob konektivity, o které hovoří Rescher, vidíme i v poslední ukázce, kde opět pozorujeme silně dostředivý efekt, který v důsledku, ,zanořuje” recipienta do vy právěním konstruovaného světa.

\section{5.}

Zbývá nám odpovědět na dvě otázky, které jsme položili v úvodu. První z nich je, zda jsme v takovýchto př́ípadech konfrontováni s fikcí, druhou, kdo je subjektem vyprávění v takovýchto příznakových seg-

\footnotetext{
${ }^{25} \mathrm{~V}$ průběhu analýzy textu jsme získali subjektivní dojem, že fikcionalizované segmenty obecně disponují kratšími větami, respektive souvětími. Statistická analýza textu ovšem ukázala, že rozdíly mezi těmi segmenty, které jsme vyznačili jako výrazně fikcionalizované (cca $56 \%$ z celkového rozsahu textu) a segmenty $\mathrm{s}$ dominantím atributem autorské vzpomínky, se od sebe $\mathrm{v}$ tomto ohledu zvláště neliší. (Průměrná délka věty se $\mathrm{v}$ tomto textu pohybuje v plynulém rozmezí 13-19 slov.) Zmíněný rozdíl spočívá $\mathrm{v}$ něčem jiném, a to ve změně typu souvětí, kdy pro fikcionalizované segmenty je příznačnější parataxe s kratšími větnými komponenty. To vyvolává náležitou narativní dynamiku.
} 
mentech; je jím stále autor Ignát Herrmann, anebo fikční vypravěč? Jelikož se většinou fikce nevykazuje obecně platným invariantem, její rozpoznávání je obtížné založit na výhradně formálních atributech. $\mathrm{Na}$ straně druhé fikce nevytváŕí izolované dimenze, které by nebyly schopny komunikovat s dimenzemi non-fikčními. A nemusí se zrovna jednat o postmoderní díla, aby $\mathrm{k}$ této skutečnosti docházelo zcela plynule a téměř nepozorovaně. Toho jsme svým způsobem svědky i v př́ppadě některých Herrmannových vzpomínek. Domníváme se, že se jedná o z části bezděčný postup, jak dokládá také skladba posledně uvedené vzpomínky. Ta je totiž autorem rozčleněna na relativně samostatné části, z nichž některé vznikaly dodatečně, s časovým odstupem, jiné byly koncipovány ve zjevné autorově snaze zpracovat životní látku novým způsobem, který by jí dal vyniknout $\mathrm{v}$ její životnost a konkrétnosti. A možná motivován touto snahou přistupuje Herrmann ke struktuře, která má oproti dosavadnímu způsobu vyprávění výrazný potenciál fikcionalizovat vyprávěné a sugerovat či evokovat fikční svět. (Paradoxně se tak autor prohřešuje proti svému původnímu předsevzetí vyprávět jen podle skutečnosti a nefabulovat.)

Označit tyto fikcionalizované pasáže za literární fikci však není možné. ${ }^{26}$ To, co nám v tom brání, jsou širší kontexty, které subsumují dané segmenty pod non-fikční žánr autorských vzpomínek. Jinými slovy, autorská intence a gravitační síla non-fikčního žánru jsou dostatečně silné na to, aby zabránily dominanci fikce. Na druhé straně však nejsou schopny zamezit jejímu vpádu do non-fikčního diskurzu, který tímto dostává zajímavé ontologické trhliny. Ačkoli uvedené pasáže budeme $\mathrm{z}$ pragmatického hlediska ve výsledku připisovat autorovi a jeho non-fikční referenci, latentně oscilujeme na osmotické hranici obou dimenzí.

Podobně nejednoznačná je odpověd' na otázku, kdo vypráví tyto fikcionalizované části. Spíše nežli jednoznačné stanovisko nabízíme uvažovat na široké škále mezi autorem a vypravěčem. Vyprávějícím subjektem non-fikčních částí vzpomínek je autor. Bylo by ovšem na

${ }^{26}$ Proto jsme také pro ně zvolili označení fikcionalizované. místě hovořit o non-fikčním autorském textovém konstruktu, tj. „Ignátu Herrmannovi”, který je - i když to mnohdy nemusí být nijak zásadní - odlišný od civilního Ignáta Herrmanna, který je sám o sobě komplexnější entitou, jež se výhradně nezabývá pouze vzpomínkami a jejich vyprávěním. Ovšem $v$ rámci tohoto vzpomínkového vyprávění je konstruován další vypovídající subjekt, který je v dalším mezistupni mezi tímto „Ignátem Herrmannem” a fikcionalizovaným vypravěčem. Tak, jako jsou fluidní hranice mezi fikcí a non-fikcí, existuje $\mathrm{i}$ řada přechodných pásem mezi autorským a vyprávěcím já.

Nejednoznačné odpovědi, které jsme v závěru poskytli, nemusí být nutně ke škodě věci. Na vybraných částech Herrmannových vzpomínek jsme se pokusili doložit obecnější jev, který lze označit jako osmózu mezi fikcí a nonfikcí. Tato přirozená propustnost se projevuje v neustále těkavých modifikacích nejen toho, co je zobrazováno a k čemu je odkazováno, ale i subjektů, kteří se těchto komunikačních procesů účastní. Fikce má zásadní schopnost infiltrovat nonfikční diskurzy a vice versa. Zdá se, že jedno bez druhého by bud'to nemohlo existovat, anebo by existovalo za zcela změněných obecných podmínek. Jak fikce, tak nonfikce slouží ke konceptualizaci naší skutečnosti. Obě dimenze plní vlastní specifické úkoly a jsou svým způsobem nezbytné, nebot' - jak to opět výstižně vyjádřil Rescher - ,, $[$ h]omo sapiens je obojživelník, který žije v říši reality a také v ř́iši posibility. Ztráta druhé říše zmenšuje samu naši povahu. A žádný z našich zdrojů není výkonnějším a účinnějším vstupem do této říše než fikce" (Rescher 2017, s. 57).

Ve 20. a 21. století se autobiografické vyprávění s výraznými prvky fikce stává běžnější součástí literatury. Zejména postmoderní autofikce (nejen) podle Foniokové programově oscilují mezi fikcí a non-fikcí, takže je pro čtenáře takovéhoto hybridního žánru (Fonioková 2018, s. 851-852) mnohdy obtížné jednoznačně určit, zda se aktuálně pohybuje $\mathrm{v}$ pásmu biografického dokumentu anebo již v oblasti fikčního světa. Případ jmenovaných Herrmannových vzpomínkových textů je ovšem jiný. Jestliže autofikce vyplývá ze záměru autora koncipovat svoji biografii jako hybridní diskurz, Herrmann své vzpomín- 
ky psal s jednoznačným záměrem evokovat ve čtenářích obraz zaniklého staropražského světa, který by nebyl fabulován, ale co možná nejpřesněji vyvoláván z autorovy paměti. Na řadě míst svých vzpomínek to také explicitně uvádí, že jeho snahou je podávat pouze pravdivé a nezkreslené informace. Referenční relevantnost Herrmannových výpovědí dokládají i ohlasy jeho původně časopisecky publikovaných vzpomínek ze staré Prahy, kdy mu do redakce chodily dopisy čtenářo̊n, kteří na základě vlastní zkušensoti doplňovali ty z informací, u kterých si autor po čase již nebyl jist. Přes veškeré úsilí po objektivitě a faktičnosti se do Herrmannových vzpomínek dostávají části, které jeho vyprávění výrazně epizují a posunují k modu fikčního vyprávění. O autonomní fikci se však nejedná, nebot' nedochází k rozvíjení a budování fikčního kontinua; jedná se pouze o jakési trsy. Přesto se ukazuje, jak obě polarity spolu téměř bytostně souvisí a jak hranice mezi oběma bývá mnohdy velmi jemná.

\section{Literatura}

A 11 é n S. (ed.), 2012, Možné světy v humanitnich vědách, v umění a v prírodnich védách, Praha: Academia.

F o n i o k o vá Z., 2018, Fikčnost ve faktuálním vyprávěni: př́pad fikčnich metaautobiografií, „Česká literatura” LXVI, č. 6, s. 841-869.

Frynta E., 1959, Herrmannovy pražské vzpominky, [in:] O Praze a Pražanech, Praha: Československý spisovatel.

G e n e t t e G., 2007, Fikce a vyprávění, přel. E. Brechtová, Praha: Ústav pro českou literaturu AV ČR.

H e r r m a n n I., 1924, Před padesáti lety I, Praha: F. Topič.

H e r r m a n n I., 1925, Před padesáti lety II, Praha: F. Topič.

H e r r m a n n I., 1926, Před padesáti lety III, Praha: F. Topič.

H e r r m a n n I., 1959, O Praze a Pražanech, Praha: Československý spisovatel.

Martín e z-B on a ti F., 2017, O fikčním diskurzu, [in:] O fikci nově, přel. L. Doležel, Praha: Academia., s. 91-104.

Mihailescu C.-A., Hamarneh W. (eds.), 2017, O fikci nově, Praha: Academia.

N e r u d a J., 1966, Povidky malostranské, Praha: Státní pedagogické nakladatelství. O u 11 e t P., 2017, Vnímání fikčních světů, [in:] O fikci nově, přel. L. Doležel. Praha: Academia, s. 105-123.

P a v e 1 T., 2012, Fikčni světy, přel. H. Zykmund, Praha: Academia.
R e s c h e r N., 2017, Otázky o povaze fikce, [in:] O fikci nově, přel. L. Doležel, Praha: Academia, s. 47-58.

R o n e n o vá R., 2006, Možné světy v teorii literatury, přel. M. Červneka, Brno: Host.

W o o d s J., 2017, Pevnost Fikce, [in:] O fikci nově, přel. L. Doležel, Praha: Academia, s. 59-70. 